\title{
Density assumptions for converting geodetic glacier volume change to mass change
}

\author{
M. Huss \\ Department of Geosciences, University of Fribourg, 1700 Fribourg, Switzerland \\ Correspondence to: M. Huss (matthias.huss@unifr.ch) \\ Received: 16 December 2012 - Published in The Cryosphere Discuss.: 11 January 2013 \\ Revised: 21 April 2013 - Accepted: 2 May 2013 - Published: 27 May 2013
}

\begin{abstract}
The geodetic method is widely used for assessing changes in the mass balance of mountain glaciers. However, comparison of repeated digital elevation models only provides a glacier volume change that must be converted to a change in mass using a density assumption or model. This study investigates the use of a constant factor for the volumeto-mass conversion based on a firn compaction model applied to simplified glacier geometries with idealized climate forcing, and two glaciers with long-term mass balance series. It is shown that the "density" of geodetic volume change is not a constant factor and is systematically smaller than ice density in most cases. This is explained by the accretion/removal of low-density firn layers, and changes in the firn density profile with positive/negative mass balance. Assuming a value of $850 \pm 60 \mathrm{~kg} \mathrm{~m}^{-3}$ to convert volume change to mass change is appropriate for a wide range of conditions. For short time intervals ( $\leq 3 \mathrm{yr}$ ), periods with limited volume change, and/or changing mass balance gradients, the conversion factor can however vary from $0-2000 \mathrm{~kg} \mathrm{~m}^{-3}$ and beyond, which requires caution when interpreting glacier mass changes based on geodetic surveys.
\end{abstract}

\section{Introduction}

Determination of glacier mass balance via the comparison of two terrain elevation models obtained from air- or spaceborne observation is one of the most popular and accurate methods to monitor glacier mass change over periods of a few years to some decades (e.g. Rignot et al., 2003; Bamber and Rivera, 2007; Cogley, 2009; Nuth et al., 2010; and Gardelle et al., 2012). Geodetic measurements of the glacier mass budget are powerful as large and inaccessible areas can be covered and the integrated changes of the whole glacier system are captured. However, the differencing of digital elevation models (DEMs) provides a change in glacier volume instead of a mass change that is the relevant quantity for climate impact assessments (e.g. sea-level rise contribution and mountain hydrology). In glaciological studies, observable volume change $\Delta V$ is usually converted to a mass change $\Delta M$ by assuming a conversion factor $f_{\Delta V}$ as

$\Delta M=f_{\Delta V} \cdot \Delta V$.

The robustness of $f_{\Delta V}$ in time and space is crucial for the accuracy of geodetic mass balance determination but has received little attention so far.

It can be shown that the factor $f_{\Delta V}$ varies from case to case, and is inherently difficult to determine. A temporal change in glacier mass $M$ is given by the change in glacier volume $V$ multiplied by its density $\rho$ as

$\frac{\partial M}{\partial t}=\frac{\partial(\rho V)}{\partial t}$.

Integrated with time this yields

$\Delta M=\Delta \rho V+\Delta V \rho$,

where $\rho$ is the bulk density of the glacier including its firn coverage, and $\Delta \rho$ is the change in average glacier density over the time interval considered. In practice, the exact individual quantification of $\Delta \rho, \rho$ and $V$ is however close to impossible. If we write Eq. (3) as

$\Delta M=\left(\frac{\Delta \rho V}{\Delta V}+\rho\right) \cdot \Delta V=f_{\Delta V} \cdot \Delta V$,

the terms $\Delta \rho, \rho$ and $V$ can be lumped into the conversion factor $f_{\Delta V}$ which allows direct calculation of mass change from 
volume change. Nevertheless, it is evident from this formulation that $f_{\Delta V}$ will not be a straight-forward constant.

Most studies make basic assumptions on the conversion factor between volume change and mass change and often rely on Sorge's law (Bader, 1954) that prescribes no changes in the vertical firn density profile over time. If Sorge's law holds, $\Delta \rho$ (Eq. 3) equals zero, and $f_{\Delta V}$ is about $900 \mathrm{~kg} \mathrm{~m}^{-3}$. This number derives from the density of ice and has been adopted in many previous assessments of geodetic mass balance of mountain glaciers (e.g. Cox and March, 2004; Bauder et al., 2007; Paul and Haeberli, 2008; and Cogley, 2009). A significant change in volume however implies either positive or negative mass balance, and hence a shift in the firn line, as well as a change in firn thickness and average density, thus directly contradicting Sorge's law. Based on a simple analysis of firn area changes, Sapiano et al. (1998) estimated the average "density" of volume change as $850 \mathrm{~kg} \mathrm{~m}^{-3}$. Several recent studies have adopted this value in order to account for the effect of increasing or decreasing firn thickness on $f_{\Delta V}$ (Huss et al., 2009; Zemp et al., 2010, 2013; Fischer, $2010,2011)$. Another approach is to use zonally variable conversion factors (Schiefer et al., 2007; Moholdt et al., 2010; Gardelle et al., 2012; Kaeaeb et al., 2012). The uncertainty range due to the density assumption is explored by either setting $f_{\Delta V}=900 \mathrm{~kg} \mathrm{~m}^{-3}$ for the entire glacier, or $900 \mathrm{~kg} \mathrm{~m}^{-3}$ in the ablation area, and 500 to $600 \mathrm{~kg} \mathrm{~m}^{-3}$ in the firn zone for converting volume changes to mass changes. Sørensen et al. (2011) and Bolch et al. (2013) refined this approach by assessing firn densities above the equilibrium line altitude (ELA) of the Greenland ice sheet or Arctic ice caps using firn compaction models.

Based on a non-steady firn densification model for the percolation zone of Greenland, Reeh (2008) concludes that the "straight-forward translation of observed short-term ice sheet surface-elevation variations into mass changes may be completely misleading." This is explained by the transient adaptations of the firn density profile in response to temporally varying melt and accumulation rates. Helsen et al. (2008) show that surface elevation changes in the interior of Antarctica are mainly due to firn depth variations and cannot be interpreted as a mass change. These findings related to ice sheet mass balance are also relevant regarding mountain glaciers; surface elevation in the accumulation area, and hence glacier volume, is not coupled linearly to glacier mass.

Assessing the robustness of the conversion factor $f_{\Delta V}$ necessarily involves the application of a model that links the mass of a glacier to its volume by quantifying the terms of Eq. (3). Volume change can be determined quite accurately using photogrammetry (e.g. Bauder et al., 2007; and Nuth et al., 2010) or laser-scanning techniques (e.g. Abermann et al., 2010). Annual glacier mass change is normally estimated with the direct glaciological method (e.g. Kaser et al., 2003) by integrating surface-density corrected point measurements over the glacier area. Several studies however show that systematic differences between the glacio- logical and the geodetic method are difficult to interpret as they might be explained by various poorly constrained sources of uncertainty (Fischer, 2011; Zemp et al., 2013). At the mountain-range scale, glacier mass change can also be directly measured with satellite-based observations using gravimetry (e.g. Jacob et al., 2012), but the uncertainties are still considerable and the spatial resolution is too low for providing mass variations of individual glaciers. Groundbased gravimetry has also been applied for detecting local mass changes (Breili and Rolstad, 2009). Application of the method for determining the overall glacier mass budget is however not feasible.

To date, detailed studies for mountain glaciers that connect geodetically measured variations in overall ice volume to their mass balance by taking into account changes in firn volume and density at a spatially distributed scale are not available. In order to investigate the value and the temporal robustness of the conversion factor $f_{\Delta V}$ (Eq. 1), an empirical firn densification model coupled to idealized surface mass balance forcing is applied to a range of simplified glacier geometries. Further, the evolution of firn thickness and density since 1960 is simulated for two glaciers in the Swiss Alps based on long-term mass balance observations, and the changes in mass and volume are jointly discussed. This study provides recommendations for the "density" of volume change $f_{\Delta V}$ to be used in mass balance studies based on the geodetic method, and demonstrates in which cases the assumption of a straight-forward conversion factor fails.

\section{Data and methods}

\subsection{Glacier geometry}

$f_{\Delta V}$ is assessed at two stages: (1) for synthetic glacier geometries, and (2) in case studies with field data for the $50 \mathrm{yr}$ time series of surface mass balance for the Griesgletscher and Silvrettagletscher, Swiss Alps. This has the advantage that, at stage 1, the response of glacier volume to a prescribed idealized mass balance forcing can be discussed under controlled conditions, depicting the dominant features, and at stage 2 , these findings are put into the applied context of a glacier monitoring program.

A strongly simplified synthetic glacier geometry is defined at stage 1 . The glacier is a slab with a constant slope of $15^{\circ}$, a constant width and a given elevation range (between $300 \mathrm{~m}$ and $2000 \mathrm{~m}$ ). For the whole modelling exercise, glacier geometry is assumed to remain constant, i.e. a dynamic response of ice flow is not accounted for.

Griesgletscher $\left(4.97 \mathrm{~km}^{2}\right)$ and Silvrettagletscher $\left(2.79 \mathrm{~km}^{2}\right.$, both in 2007$)$ are typical medium-sized alpine glaciers in the southern and eastern Swiss Alps (Fig. 1). A mass balance monitoring program is maintained since 1960 on both glaciers (Glaciological Reports, 1960-2011). Annual mass balance is determined using the glaciological 


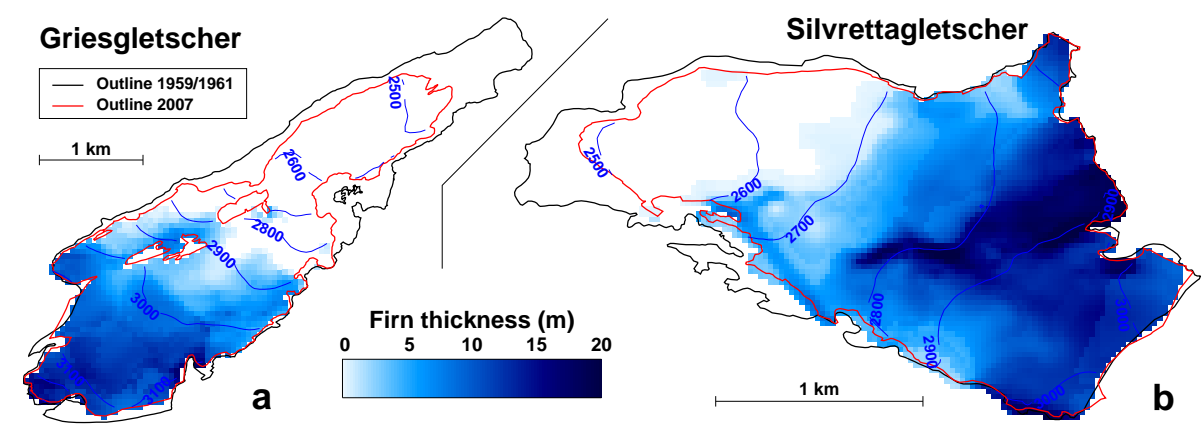

Fig. 1. Overview maps of (a) Griesgletscher and (b) Silvrettagletscher (enlarged by a factor 2), Swiss Alps, with glacier outlines around 1960 and in 2007, and modelled firn thickness (see below) in 1985 (down to pore close-off at $830 \mathrm{~kg} \mathrm{~m}^{-3}$ ).

Table 1. Firn density data compiled from studies on temperate and polythermal glaciers in different mountain ranges. For each firn core the average density of the first $10 \mathrm{~m} \overline{\rho_{10}}$ (in $\left.\mathrm{kg} \mathrm{m}^{-3}\right)$, the approximate mean accumulation rate $b\left(\mathrm{~m} \mathrm{w.e.} \mathrm{a}^{-1}\right)$, and a qualitative statement about the thermal regime is given (temperate/polythermal). Some studies provide more than one firn core $\left(n_{\mathrm{c}}\right)$, and values refer to an average.

\begin{tabular}{llrrrr}
\hline Reference & Location & $n_{\mathrm{c}}$ & $\overline{\rho_{10}}$ & $b$ & type \\
\hline Ambach and Eisner (1966) & European Alps & 1 & 700 & 1.2 & temp. \\
Oerter et al. (1982) & European Alps & 3 & 600 & $\approx 1$ & temp. \\
Sharp (1951) & Western Canada & 1 & 650 & $\approx 1.5$ & temp. \\
Zdanowicz et al. (2012) & Arctic Canada & 2 & 560 & $0.3-0.6$ & polyth. \\
Kreutz et al. (2001) & Tien Shan & 1 & 650 & 1.3 & polyth. \\
Suslow and Krenke (1980) & Pamir & 1 & 620 & $\approx 1$ & polyth. \\
He et al. (2002) & Himalaya & 1 & 640 & 0.9 & polyth. \\
Matsuoka and Naruse (1999) & Patagonia & 1 & 620 & 2.2 & temp. \\
Shiraiwa et al. (2002) & Patagonia & 4 & 550 & $5-15$ & temp. \\
Pälli et al. (2002) & Svalbard & 1 & 510 & 0.4 & polyth. \\
Nuth et al. (2010) & Svalbard & 3 & 510 & $\approx 0.5$ & polyth. \\
\hline
\end{tabular}

method. Eight (Gries) and six (Silvretta) DEMs are available over the last five decades, documenting changes in glacier area and volume (Bauder et al., 2007). Both mass balance series were homogenized by Huss et al. (2009).

\subsection{Firn densification}

The processes of firn densification have been extensively studied for conditions below freezing level (e.g. Herron and Langway, 1980; Arthern and Wingham, 1998; Li and Zwally, 2004; Reeh, 2008; and Ligtenberg et al., 2011). However, there are few modelling approaches for temperate firn (e.g. Vimeux et al., 2009), and densification rates can be higher by one order of magnitude compared to cold firn (Kawashima and Yamada, 1996; Cuffey and Paterson, 2010). The processes governing firn compaction (pressure, aging) are active for both temperate and cold conditions thus allowing a similar description. For mountain glaciers, also refreezing of liquid water in the pore space can accelerate firn densification (Schneider and Jansson, 2004). Even in the case of temperate glaciers refreezing can be significant as winter temperatures tend to seasonally cool the uppermost firn layers below $0{ }^{\circ} \mathrm{C}$ (e.g. Hooke et al., 1983). Physical modelling of the refreez- ing rate requires the description of heat conduction and data on the surface temperature forcing (e.g. Reijmer and Hock, 2008; and Ligtenberg et al., 2011).

Here, the classical firn densification model by Herron and Langway (1980) developed for the Greenland ice sheet (HL model) modified for the temperate/polythermal firn of mountain glaciers is employed. The model is suitable for nonsteady conditions as described by Reeh (2008), and calculates the density $\rho_{\text {firn }}\left(t_{0}, t\right)$ of the firn layer deposited at time $t_{0}$ after a time span of $t \mathrm{yr}$ as

$\rho_{\text {firn }}\left(t_{0}, t\right)=\rho_{\text {ice }}-\left(\rho_{\text {ice }}-\rho_{\text {firn }, 0}\right) \cdot \exp (-c \cdot t)+R F(t)$,

where $\rho_{\text {ice }}$ is the density of ice, $\rho_{\text {firn }, 0}$ the density of new firn, and $R F(t)$ accounts for densification due to refreezing of melt water. A value of $\rho_{\text {ice }}=900 \mathrm{~kg} \mathrm{~m}^{-3}$ is assumed as representative for mountain glaciers, and $\rho_{\text {firn }, 0}$ is set to $490 \mathrm{~kg} \mathrm{~m}^{-3}$ according to the average density of the uppermost annual firn layer of 19 density profiles compiled from mountain glaciers in different climatic regimes (Table 1).

The HL model specifies two phases of compaction in dry firn. Here, the first densification phase (according to Herron and Langway (1980) for $\rho<550 \mathrm{~kg} \mathrm{~m}^{-3}$ ) is not considered as 
it is assumed to mostly take place in the first year after snow deposition and to only have a minor importance for mountain glaciers. The parameter $c$ of Eq. 5 is defined as

$c=k_{1}\left(b \cdot \rho_{\text {ice }} / \rho_{\mathrm{W}}\right)^{1 / 2}$,

with $b$ the annual accumulation rate in meters water equivalent (w.e.) and $\rho_{\mathrm{w}}$ the density of water. The term $k_{1}$ is constant for temperate conditions and is given as

$k_{1}=f \cdot \exp \left(\frac{-21400}{R T}\right)$

where $R$ is the gas constant, $T$ the firn temperature in $\mathrm{K}$, and $f$ a factor that was empirically determined by Herron and Langway (1980). In this study, $f$ is used to tune simulated to observed firn densification (see below).

In order to keep the model simple (not requiring climate data input) and location-independent, firn densification due to refreezing $R F(t)$ (Eq. 5) is roughly approximated by assuming an end-of-winter firn temperature profile that linearly increases from $-5^{\circ} \mathrm{C}$ at the firn surface to $0^{\circ} \mathrm{C}$ at a depth of $5 \mathrm{~m}$. This profile corresponds to the typical penetration depth of winter air temperatures (e.g. Hooke et al., 1983; and Greuell and Oerlemans, 1989) and defines a negative heat reservoir for refreezing melt water. For each firn layer, refreezing $r$ is obtained by prescribing complete latent heat exchange. Total refreezing $R F(t)$ after $t$ yr is calculated as $R F(t)=R F(t-1)+r$. After pore close-off at $830 \mathrm{~kg} \mathrm{~m}^{-3}$, a linear densification rate with age of $10 \mathrm{~kg} \mathrm{~m}^{-3} \mathrm{a}^{-1}$ is assumed until ice density is reached.

Density measurements from 19 firn cores acquired on mountain glaciers or ice caps were compiled for calibrating the firn compaction model (see Table 1 for references). Firn cores reach depths of 10-22 $\mathrm{m}$ and are available for the European Alps, Western and Arctic Canada, Central Asia, Patagonia, and Svalbard. Most cores originate from temperate firn, but some glaciers are also polythermal. Detailed records that resolve the density of annual layers are provided by a $20 \mathrm{~m}$ deep firn pit on Kesselwandferner, Austria (Ambach and Eisner, 1966). The firn densification regime on this glacier is assumed to be similar as for the Gries- and Silvrettagletscher (Fig. 1). All other firn density data were averaged in $1 \mathrm{~m}$ steps resulting in a representative density-depth relation supported by data from mountain glaciers in different regions. The standard deviation of observed density is $45-88 \mathrm{~kg} \mathrm{~m}^{-3}$ over depths of $1-18 \mathrm{~m}$. The data of Kesselwandferner indicate slightly higher densities compared to the 18-core average profile but pore close-off is reached at the same depth (Fig. 2).

Application of the original HL model including an additional term for refreezing for a location with mean annual accumulation rates equal to those observed by Ambach and Eisner (1966) with $f=575$ (following Herron and Langway (1980), Eq. 7) results in too-slow firn compaction (Fig. 2). The parameter $f=1380$ is optimized to match density profiles

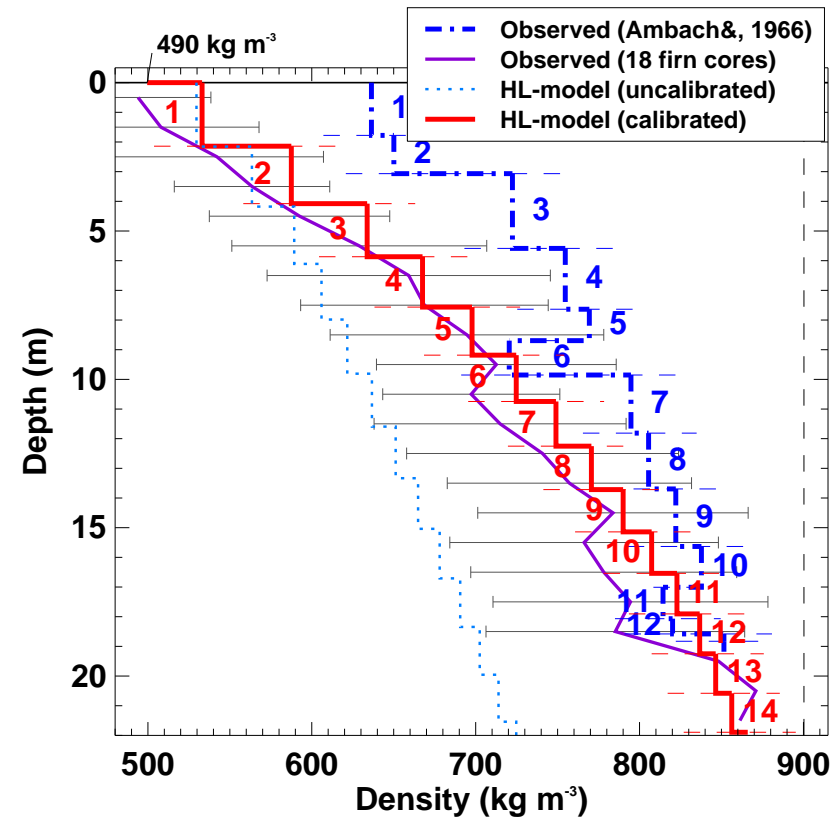

Fig. 2. Validation of calculated firn density (constant accumulation rate) against field measurements. Density of annual layers according to Ambach and Eisner (1966) and a mean density profile from 18 firn cores in different regions worldwide are shown $( \pm 1$ standard deviation given by grey bars). Numbers indicate the age of the firn layers in years.

obtained from the firn cores (Fig. 2). Densification rates with depth and age observed in different regions worldwide agree well with density calculated with the calibrated HL model indicating that this empirical approach is able to capture firn compaction for a wide range of mountain glaciers and ice caps (Fig. 2).

\subsection{Mass balance forcing}

In order to force the firn compaction model for the simplified glacier geometries, four experiments of idealized changes in surface mass balance were defined (Fig. 3). Each experiment consists of two scenarios, with a positive and a negative shift in ELA, respectively. Before applying a change in mass balance, the model is run for a $50 \mathrm{yr}$ spin-up phase with the ELA that yields a balanced mass budget. This allows convergence of the firn density profile to an equilibrium.

Surface mass balance distribution is prescribed by two linear elevation gradients $\mathrm{d} b / \mathrm{d} z$. For the ablation area $\mathrm{d} b / \mathrm{d} z=$ $0.008 \mathrm{a}^{-1}$ is assumed, and $\mathrm{d} b / \mathrm{d} z=0.004 \mathrm{a}^{-1}$ is chosen for the accumulation area. These values correspond to typically observed mass balance gradients on midlatitude mountain glaciers (e.g. WGMS, 2008). Four specific experiments are performed, and their characteristics are visualized in Fig. 3.

- Experiment I: an immediate shift of the ELA by $+100 /-100 \mathrm{~m}$ is applied after model spin-up and is maintained for $50 \mathrm{yr}$. 


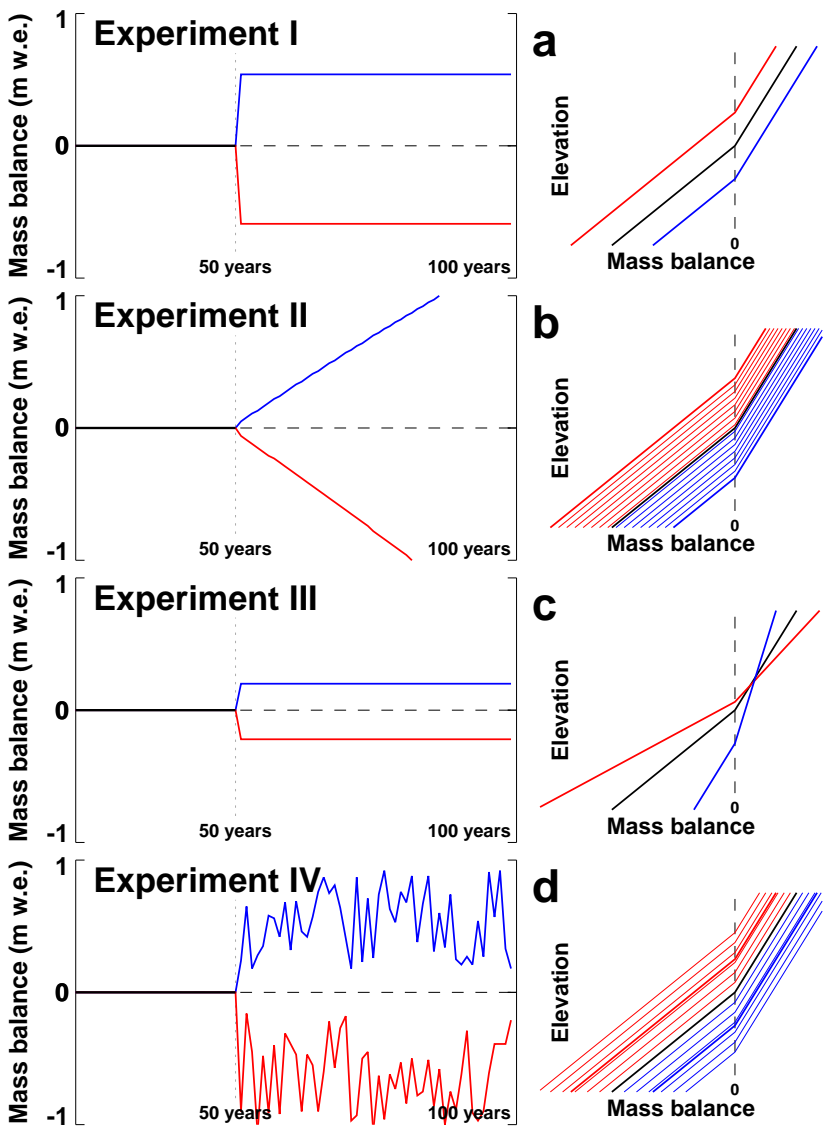

Fig. 3. Four experiments of surface mass balance forcing. Time series of glacier-wide mass balance (left), and mass balance distribution with elevation (right) are shown for each experiment. An experiment consists of two scenarios with a positive (red) and a negative (blue) shift in equilibrium line altitude.

- Experiment II: a linear increase/decrease in ELA by $5 \mathrm{ma}^{-1}$ is prescribed.

- Experiment III: the step changes in mass balance are limited but the spatial distribution is changed. Whereas the first scenario assumes a $50 \%$ increase in mass balance gradients both in the ablation and the accumulation area, the second scenario is characterized by reduced gradients. Both scenarios also include a small positive/negative shift in ELA.

- Experiment IV: a $+100 /-100 \mathrm{~m}$ shift in ELA (similar to Experiment I) is applied but a natural year-to-year variability in mass balance is superimposed.

Surface mass balance forcing for the case studies on Griesand Silvrettagletscher is provided by gridded maps of the annual mass balance distribution based on the extrapolation of the in situ measurements for the period 1961-2007, and 1959-2007, respectively (Huss et al., 2009). The glacier geometry is updated annually taking into account surface lowering and glacier retreat based on direct observations.
Both glaciers showed a balanced mass budget between the beginning of the measurements and the 1980s, and strong mass loss afterwards (Huss et al., 2009). Over the twodecadal period 1987-2007, the mean annual balance was $\overline{B_{20}}=-1.15 \mathrm{~m}$ w.e. for Gries, and $\overline{B_{20}}=-0.66 \mathrm{~m}$ w.e. for Silvretta with the ELA above the highest point of the accumulation area in several years causing a substantial degradation of the firn coverage (Fig. 1).

For both the synthetic glaciers and the case studies, mass change $\Delta M$ is calculated by integrating surface mass balance over the glacierized area. Volume change $\Delta V$ is obtained from the integration of firn layer thickness changes provided by the densification model over the entire firn column. For the ablation area, ice density is assumed to be constant at $\rho_{\text {ice }}=900 \mathrm{~kg} \mathrm{~m}^{-3}$ for calculating volume changes. Thus, Eq. (1) can be solved and the conversion factor $f_{\Delta V}$ between volume change and mass change can be calculated for arbitrary periods of one year to several decades.

\section{Results}

\section{1 $f_{\Delta V}$ for idealized glaciers}

For each of the four experiments (Fig. 3), the combined model for surface mass balance forcing and firn compaction is run, providing annual series of the change in glacier mass and volume. Figure 4 shows the conversion factor $f_{\Delta V}$ for observation periods of geodetic volume change that start with the step change in climate forcing and increase in length from 1 to $50 \mathrm{yr}$.

After a shift in ELA, $f_{\Delta V}$ converges towards $900 \mathrm{~kg} \mathrm{~m}^{-3}$ after some decades. When the firn density profile is allowed sufficient time to adapt, the cumulative volume loss in the ablation area (with $\rho_{\text {ice }}$ ) tends to dominate the changes in the firn area. For periods shorter than about two decades, $f_{\Delta V}$ can however be significantly lower than $900 \mathrm{~kg} \mathrm{~m}^{-3}$ (Experiment I), both in the case of positive and negative volume change (Fig. 4a, Table 2). Firn layers with a density smaller than $\rho_{\text {ice }}$ are added/removed which tends to make the glacier volume change larger than implied by the first order approximation of $f_{\Delta V}=\rho_{\text {ice }}$, irrespective of the sign of mass balance change. This is also evident from Eq. (4) providing details on the components of $f_{\Delta V}$. For example, a reduction in firn coverage associated with a negative volume change $(\Delta V<0)$ leads to an increase in bulk glacier density $(\Delta \rho>0)$, and thus a value of $f_{\Delta V}$ smaller than average glacier density $\rho$.

For a linearly increasing/decreasing mass balance (Experiment II), $f_{\Delta V}$ shows a similar evolution as for Experiment I with densities of volume change between 720 and $820 \mathrm{~kg} \mathrm{~m}^{-3}$ for observation period lengths of $2-20 \mathrm{yr}(\mathrm{Ta}-$ ble 2). The response of glacier volume shows some delay as no stabilization in climate forcing is prescribed (Fig. 3). Already with a minor change in mass balance, as in the first year 

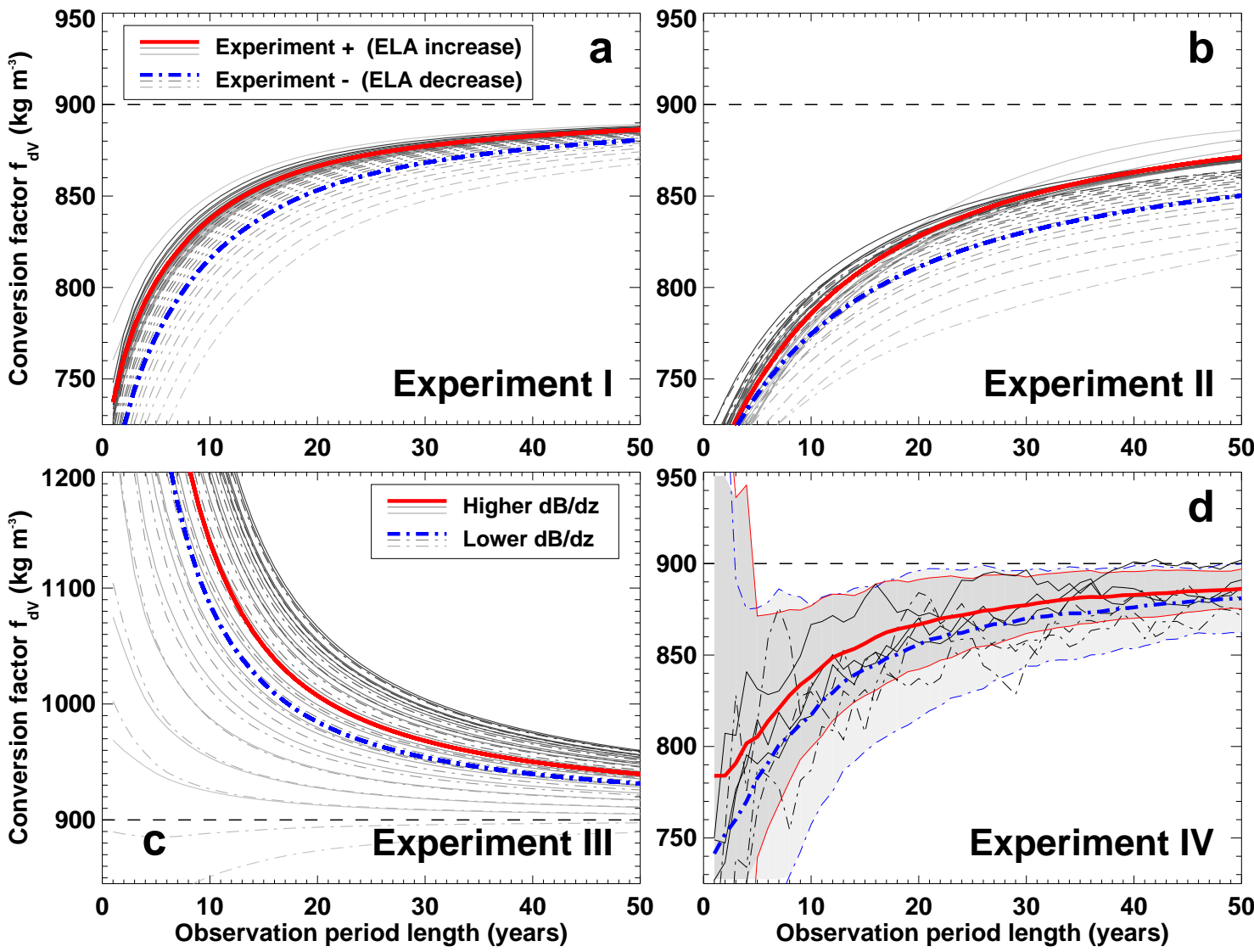

Fig. 4. Calculated conversion factor $f_{\Delta V}$ for observation period lengths increasing from 1 to $50 \mathrm{yr}$ after a change in mass balance (Fig. 3). Thin grey lines refer to model runs using different glacier size (elevation ranges 300-2000 m), solid lines show the mean of all experiment simulations for a positive/negative shift in the ELA. In (d) the variability of 200 model runs is expressed as their average \pm 2 standard deviations (shaded areas). Selected series of $f_{\Delta V}$ for individual model runs are shown.

after the spin-up phase $(\triangle \mathrm{ELA}=5 \mathrm{~m}), f_{\Delta V}$ significantly diverges from $900 \mathrm{~kg} \mathrm{~m}^{-3}$ (Fig. 4b). This indicates that assuming validity of Sorge's law for estimating the factor to convert volume change to mass change is not even feasible for a small shift in mass balance forcing although the absolute error in calculated mass change would be limited for any conversion factor.

Experiment III highlights a particular case that yields surprising results. If mass balance gradients both in the ablation and the accumulation area show a significant increase/decrease together with a relatively small change in glacier-wide mass balance, $f_{\Delta V}$ can assume values significantly larger than the density of water (Fig. 4c, Table 2). Absolute glacier volume changes are thus smaller than the associated mass changes in $\mathrm{m}^{3}$ w.e. For the case of increasing gradients (Experiment III+), volume loss with $\rho_{\text {ice }}$ is enhanced in the ablation zone, whereas the firn volume with a low average density grows in the accumulation area, partly compensating for the ice melt below the ELA. Strongly changing mass balance gradients are a rather particular response of glaciers to climate change, but may occur with rapidly rising air temperatures simultaneous to a precipitation increase as it has recently been observed in Arctic regions (e.g. Abdalati et al., 2005).

"Densities" of glacier volume change higher than $900 \mathrm{~kg} \mathrm{~m}^{-3}$ seem to be unphysical at first glance. However, the conversion factor $f_{\Delta V}$ does not necessarily correspond to the physical properties of a density (see also Eq. 4). For example, a glacier volume change $(\Delta V \neq 0)$ can occur without any change in mass $(\Delta M=0)$ purely due to compaction of the firn layers. Conversely, mass balance can be negative $(\Delta M \neq 0)$ with no change in total volume $(\Delta V=0)$ if melt increases in the ablation area, compensated in terms of volume by higher accumulation in the firn zone. According to Eq. (1) it is evident that for such special cases, $f_{\Delta V}$ can theoretically be located in the range $[-\infty, \infty]$, i.e. it can even be negative if the signs of mass change and volume change are opposite.

Experiment IV is based on a variable mass balance forcing and thus most closely represents real conditions (Fig. 3). Average $f_{\Delta V}$ over 200 model runs of different random variability shows a similar evolution as for Experiment I. The 
Table 2. Calculated conversion factor $f_{\Delta V}\left(\right.$ in $\mathrm{kg} \mathrm{m}^{-3}$ ) for all experiments (Fig. 3) and different lengths of the observation period (in years) after a change in mass balance. Scenarios with a positive $(+)$ and a negative (-) shift in ELA are shown.

\begin{tabular}{lrrrrr}
\hline & $2 \mathrm{yr}$ & $5 \mathrm{yr}$ & $10 \mathrm{yr}$ & $20 \mathrm{yr}$ & $40 \mathrm{yr}$ \\
\hline Experiment I+ & 761 & 803 & 837 & 866 & 882 \\
Experiment I- & 723 & 773 & 815 & 853 & 875 \\
Experiment II+ & 715 & 747 & 785 & 828 & 863 \\
Experiment II- & 712 & 741 & 774 & 811 & 842 \\
Experiment III+ & 1720 & 1405 & 1139 & 1007 & 950 \\
Experiment III- & 1589 & 1281 & 1085 & 984 & 939 \\
Experiment IV+ & 784 & 805 & 838 & 866 & 882 \\
Experiment IV- & 752 & 782 & 817 & 855 & 876 \\
\hline
\end{tabular}

conversion factor increases gradually from about $770 \mathrm{~kg} \mathrm{~m}^{-3}$ towards ice density with increasing observation period length (Table 2). For individual series of variable mass balance forcing, a strongly fluctuating signal is found however, in particular for observation period lengths of $\leq 3 \mathrm{yr}$ (Fig. 4d). The interplay of years with positive and negative mass balance leads to a complex pattern of the firn densification dynamics in which anomalous accumulation can impact on compaction rates for several years after deposition. If annual or multiannual mass change is close to zero, already small changes in the firn density profile can induce diverging responses of glacier volume and mass, and hence a conversion factor $f_{\Delta V}$ that is highly variable and difficult to estimate.

The dependence of $f_{\Delta V}$ on glacier size was analysed by repeated individual model runs for glacier geometries for elevation ranges of $300-2000 \mathrm{~m}$ (100 m steps). In general, the conversion factor shows similar trends for small and large glaciers although some spread is evident (Fig. 4). Whereas for scenarios with negative glacier mass balance, the elevation range has little influence on $f_{\Delta V}$ (around $\pm 10 \mathrm{~kg} \mathrm{~m}^{-3}$ ), the effect is more pronounced for an increase in ice volume. Glaciers with a limited elevation range, in particular, can show values of $f_{\Delta V}$ smaller by up to $80 \mathrm{~kg} \mathrm{~m}^{-3}$ compared to large glaciers. This is due to the higher percentage of the area of small glaciers that is affected by a given shift in the ELA. Elevation range is more influential for Experiment III; $f_{\Delta V}$ of small glaciers is below $\rho_{\text {ice }}$ (Fig. 4c) because they do not reach a critical size of the accumulation area.

Although all experiments for the synthetic glaciers indicate a significant dependence of $f_{\Delta V}$ on the period considered (Fig. 4), a general statement about a representative value of the volume-mass conversion factor and the related uncertainties is possible with some restrictions. By averaging calculated $f_{\Delta V}$ for time intervals of 5-50 yr (typical for geodetic mass balance determination) and the Experiments I, II and $\mathrm{IV}$, a mean value of $f_{\Delta V}=850 \mathrm{~kg} \mathrm{~m}^{-3}$ is found. Based on a combined assessment of the effect of glacier size and differences in $f_{\Delta V}$ for short and multi-decadal periods, an uncer- tainty range of $\pm 60 \mathrm{~kg} \mathrm{~m}^{-3}$ is assigned. In the case of (i) periods shorter than $5 \mathrm{yr}$, (ii) significant changes in the mass balance gradients (e.g. Experiment III), (iii) small overall volume changes, or (iv) an insignificant firn area, this average conversion factor might however not be applicable and $f_{\Delta V}$ can lie beyond the specified uncertainty ranges. If the above caveats are accounted for, $850 \pm 60 \mathrm{~kg} \mathrm{~m}^{-3}$ is recommended for converting volume change to mass change for studies that do not perform an in-depth analysis of changes in firn volume and density.

\subsection{Application to long-term series}

$f_{\Delta V}$ is computed based on a spatially distributed run of the firn compaction model using each year's observed mass balance distribution for Gries- and Silvrettagletscher as input after a spin-up phase. Calculated firn thickness locally reaches $20 \mathrm{~m}$ and shows a pattern related to the spatial variability of surface accumulation rates (Fig. 1). In response to a series of very negative mass balance years after the late 1980s (Glaciological Reports, 1960-2011), the thickness of the firn coverage has strongly decreased on Silvretta, and it has almost disappeared on Gries.

Comparison of observed mass balance and calculated volume change for individual years of the fluctuating signal shows that the annual conversion factor is subject to strong variability (Fig. 5a, b). This corresponds to the results of Experiment IV (Fig. 4d), and indicates that determining glacier mass balance from short-term (i.e. one to a few years) geodetic surveys might be prone to errors due to an uncertain conversion of volume change to mass change.

Evaluation of the complete series of annual conversion factors for both glaciers $(n=92)$ shows that $f_{\Delta V}$ ranges between minimum/maximum values of -500 and $6500 \mathrm{~kg} \mathrm{~m}^{-3}$ for annual mass balances $B_{\mathrm{a}}$ of -0.2 to $+0.2 \mathrm{~m}$ w.e. $\mathrm{a}^{-1}$ indicating a large relative uncertainty in the estimation of $f_{\Delta V}$ for small mass changes. The spread in $f_{\Delta V}$ rapidly reduces with increasing magnitude of mass change being $790 \pm 75 \mathrm{~kg} \mathrm{~m}^{-3}$ for $\left|B_{\mathrm{a}}\right|>1 \mathrm{~m}$ w.e. $\mathrm{a}^{-1}$. By multiplying the deviation of annually evaluated $f_{\Delta V}$ from a reference value of $850 \mathrm{~kg} \mathrm{~m}^{-3}$ with that year's mass balance, a maximum accuracy for the geodetic annual determination of mass change can be estimated. It is found that for Gries- and Silvrettagletscher $B_{\mathrm{a}}$ is subject to an uncertainty greater than at least $\pm 0.05 \mathrm{~m}$ w.e. $\mathrm{a}^{-1}$ due to the variability in $f_{\Delta V}$.

$f_{\Delta V}$ was also determined by driving the firn compaction model with observed mass balance for periods of between 4 and $14 \mathrm{yr}$ corresponding to the dates of available DEMs. This allows validating assumptions on the volume-mass conversion factor made in previous evaluations of the time series (Huss et al., 2009), and illustrates characteristic values of $f_{\Delta V}$ in applied mass balance monitoring of mountain glaciers (see e.g. Zemp et al., 2013). The results confirm the above findings. For periods with significant mass loss (i.e. all periods after the mid-1980s), $f_{\Delta V}$ is in the 

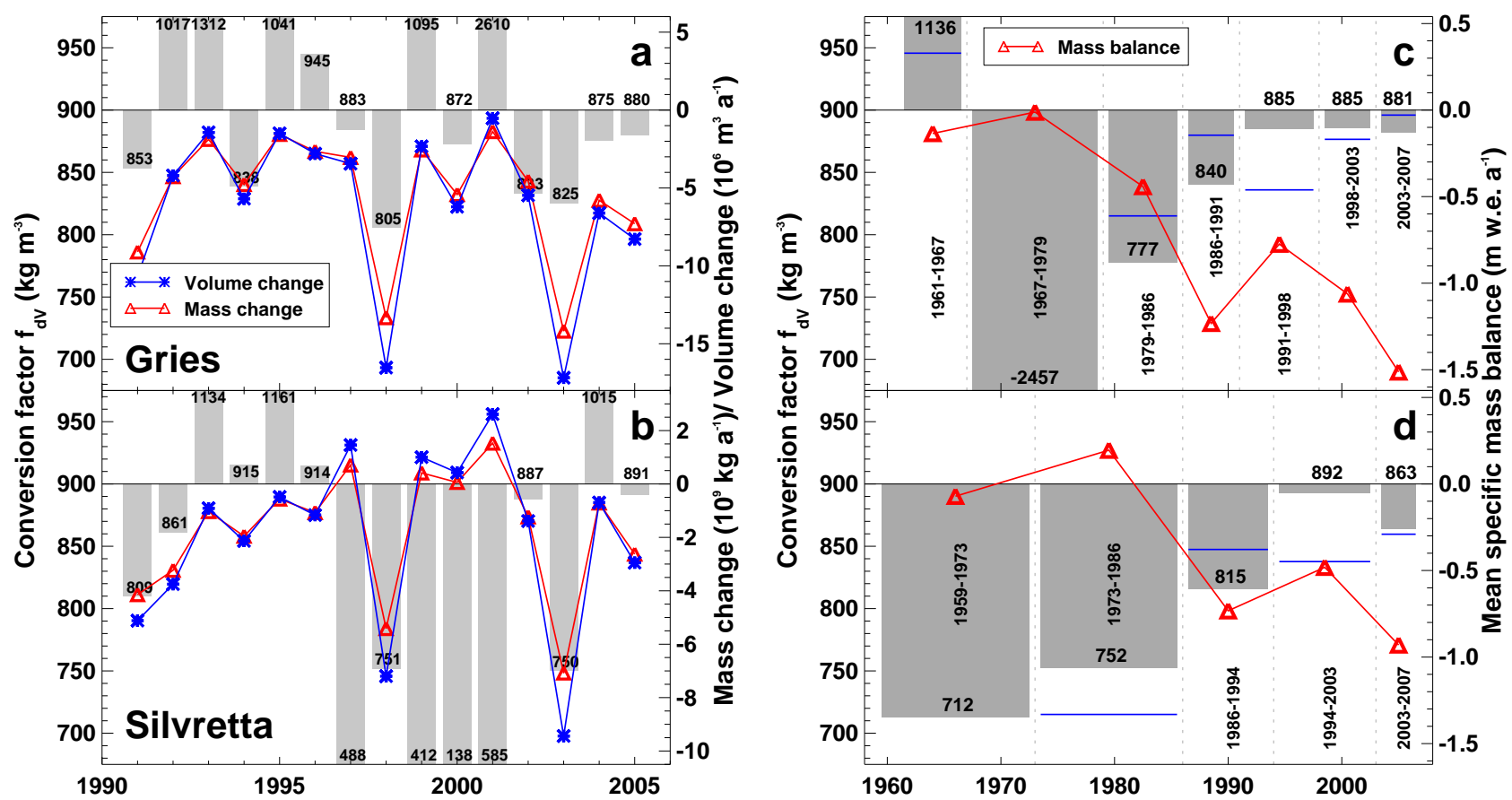

Fig. 5. Annual series of observed mass change and calculated volume change between 1990 and 2005 for (a) Griesgletscher and (b) Silvrettagletscher. The conversion factor $f_{\Delta V}$ for each year's volume change is shown by bars. Note that for bars beyond the plotted range, values are stated. (c), (d) $f_{\Delta V}$ for Gries and Silvretta over period lengths of 4-14 yr corresponding to the dates of DEMs, and observed mean

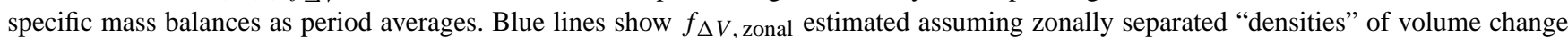
(see e.g. Moholdt et al., 2010).

range $777-892 \mathrm{~kg} \mathrm{~m}^{-3}$ (Fig. 5c, d). With ongoing climate change, the firn coverage of small to medium-sized mountain glaciers might completely disappear, resulting in a $f_{\Delta V}$ converging to ice density. From the 1960s to the early 1980s, with mean mass balances close to zero, much more variable values are found for decadal periods. Reduced "densities" of volume change prevailing during these decades are explained by increased accumulation rates leading to the build-up of thick low-density firn layers, and thus relatively large volume changes compared to the almost balanced mass budget.

$f_{\Delta V}$ is $878 \mathrm{~kg} \mathrm{~m}^{-3}$ for Gries, and $866 \mathrm{~kg} \mathrm{~m}^{-3}$ for Silvretta for the entire 5-decadal observation period. Considering the components of $f_{\Delta V}$ (Eq. 4), these numbers seem to be reasonable given a bulk glacier density $\rho$ of slightly below $900 \mathrm{~kg} \mathrm{~m}^{-3}$ (volume-weighted average of mean firn and ice densities), and the changes in glacier density $\Delta \rho$ and volume $\Delta V$ over time.

The suitability of using separate conversion factors for volume changes in the accumulation and the ablation area (e.g. Moholdt et al., 2010; Kaeaeb et al., 2012; and Bolch et al., 2013) was assessed by evaluating zonal surface elevation changes between two DEMs. Geodetic mass change was calculated using a "density" of volume change of $600 \mathrm{~kg} \mathrm{~m}^{-3}$ in the firn area, and $900 \mathrm{~kg} \mathrm{~m}^{-3}$ below. Resulting changes in overall mass and volume were compared providing $f_{\Delta V}$, zonal for all decadal periods (Fig. 5c, d). This relatively simple ap- proach that avoids assuming a constant volume-mass conversion factor over time is able to reproduce some of the decadal variability in $f_{\Delta V}$ found with the firn compaction model. It does, however, not take into account that changes in firn volume and density might not be revealed as variations in surface elevation due to ice flow dynamics. Hence, this method only captures part of the effect and might underestimate the uncertainties.

\section{Discussion}

Although Figs. 4 and 5 suggest that values of $f_{\Delta V}$ may be erratic - being beyond the physical ranges of snow or ice density - these results do not challenge the usefulness of the geodetic method but indicate that caution is required in some cases when interpreting the results. It has been shown that calculated conversion factors outside of a range of roughly $750-900 \mathrm{~kg} \mathrm{~m}^{-3}$ occur in connection with (i) short observation periods (1-3yr), (ii) small volume changes, (iii) strong changes in the mass balance gradients, or a combination of these factors. In practice, (i) can be circumvented by conducting geodetic surveys over sufficiently long time periods. About 5-10 yr seem to be appropriate to significantly reduce the uncertainties inherent to DEM production, and the density assumption (see also Thibert et al., 2008; Zemp et al., 2013). For case (ii), highly variable $f_{\Delta V}$ result in relatively 
small absolute errors in calculated mass change as they occur in connection to an almost balanced mass budget (Fig. 5). Significant changes in mass balance gradients (iii) with a limited magnitude of glacier mass loss/gain (Fig. 3c) are related to a major shift in climatic conditions. This particular case needs to be carefully addressed if there are hints that these constraints are met. By accounting for the three above restrictions in the application of the geodetic method, problems arising from an uncertain conversion factor can be tackled and be reduced to an acceptable level.

All evaluations presented in this paper refer to landterminating glaciers. Ice volume loss by calving is not included in the model and would require the explicit description of ice flow dynamics. General concepts, such as the dependence of $f_{\Delta V}$ on the time period considered, and the high variability of the conversion factor for particular cases, are however assumed to be valid for marine-terminating glaciers as well.

Several sensitivity tests were performed to investigate the robustness of calculated $f_{\Delta V}$ on changes in the synthetic glacier geometries and simplifications in the modelling of firn densification. The model was run with idealized mass balance forcing for all experiments (Fig. 3). Differences in the computed conversion factor were compared to the "reference" results (shown in Fig. 4 and Table 2) and outcomes are discussed hereafter.

In a first experiment, additional synthetic glaciers were defined for analysing the dependence of $f_{\Delta V}$ on glacier geometry: (1) the glacier with a constant width has a slope of $8^{\circ}$ below half of its elevation range, and is steep $\left(35^{\circ}\right)$ in its upper reaches; (2) it is inclined by $35^{\circ}$ in the ablation area, and $8^{\circ}$ in the accumulation area; and (3) the width of the accumulation area is increased by a factor 5 relative to the ablation area (with a constant slope of $15^{\circ}$ ). The areaelevation distribution of the glacier has a small influence on $f_{\Delta V}$. Slightly higher average values were found for a glacier exhibiting a steep firn zone $\left(+1 \mathrm{~kg} \mathrm{~m}^{-3}\right.$, excluding Experiment III), and lower $f_{\Delta V}$ is present for the glacier geometry with a steep ablation area $\left(-18 \mathrm{~kg} \mathrm{~m}^{-3}\right)$. Increasing the width of the accumulation area yields a difference in average $f_{\Delta V}$ of $-19 \mathrm{~kg} \mathrm{~m}^{-3}$.

Assessing the performance and the suitability of the HL model for mountain glaciers is difficult due to the paucity of direct field evidence (the parameters of Eq. (5) are poorly constrained). To test the impact of the approach to model firn compaction on calculated $f_{\Delta V}$, a simple linear firn density change with age fitted to the mean observed density profile was considered. Assuming a constant densification rate of $35 \mathrm{~kg} \mathrm{~m}^{-3} \mathrm{a}^{-1}$ yields results for $f_{\Delta V}$ that are lower by $15 \mathrm{~kg} \mathrm{~m}^{-3}$ on average (excluding Experiment III) compared to the reference. Varying the initial firn density $\rho_{\text {firn }, 0}$ between the minimum and the maximum of the observed values (Table 1) leads to changes in $f_{\Delta V}$ of -31 and $+26 \mathrm{~kg} \mathrm{~m}^{-3}$, respectively.
The sensitivity of $f_{\Delta V}$ on the climate regime, i.e. the surface mass balance distribution, and potential changes in characteristic compaction rates with higher temperatures, was analysed (i) by reducing balance gradients by a factor 2 for all experiments, corresponding to more continental conditions, and (ii) by increasing the amount of refreezing $R F(t)$ (Eq. 5) by $100 \%$. The approach to model $f_{\Delta V}$ is relatively insensitive even to these major changes in firn compaction. For reduced mass balance gradients, the average conversion factor is $10 \mathrm{~kg} \mathrm{~m}^{-3}$ below the reference results (excluding Experiment III). Doubling the refreezing rate $R F(t)$ causes an increase in average $f_{\Delta V}$ by $+20 \mathrm{~kg} \mathrm{~m}^{-3}$. More refreezing is expected in a warming climate for cold or polythermal glaciers (e.g. Zdanowicz et al., 2012). For temperate mountain glaciers, higher temperatures will however rather reduce $R F(t)$.

The sensitivity tests indicate that calculated $f_{\Delta V}$ is robust regarding glacier geometry, the approach to model firn densification, and the climatic regime (continental/maritime). The conversion factor for most sensitivity tests is slightly below the reference results, but shows the same temporal trends and remains in the range of $700-900 \mathrm{~kg} \mathrm{~m}^{-3}$. The calculated average $f_{\Delta V}$ for Experiment III is higher, in contrast, for some sensitivity runs as they generally yield lower compaction rates thus exaggerating the firn volume response to a given mass balance forcing. However, the simplified setting of the experiments cannot account for all influential processes present in nature. For example, densification due to refreezing is only modelled crudely although major changes in the firn density profile of polythermal glaciers due to this process have been reported related to ongoing climate change (Zdanowicz et al., 2012).

Besides the process of firn compaction that was explicitly modelled in this study, other effects can also influence the "density" of glacier volume change. Fischer (2011) describes the impact of opening and closure of crevasses on geodetic volume change in detail. If many crevasses are present, the bulk density of the entire ice body decreases. Changes in crevasse frequency over time might lead to a bias in the conversion of volume to mass. The importance of this effect also depends on the timing (snow coverage) and the spatial resolution of the geodetic survey. Although this process might affect $f_{\Delta V}$, its magnitude is difficult to quantify and needs to be addressed for each case individually.

\section{Conclusions}

The factor for converting glacier volume change to mass change is difficult to estimate and shows a considerable variability that affects the accuracy of the widely used geodetic method for the determination of glacier mass balance. Using an empirical firn compaction model adapted for mountain glaciers, the "density" of volume change was assessed for synthetic model glaciers with idealized climate forcing, and 
for two long-term glacier monitoring programs. The conversion factor $f_{\Delta V}$ is, in most cases, below the ice density which is used in numerous studies for calculating mass balance from geodetic volume change. The effect is relatively small, yielding a typical overestimate of mass change of roughly $2-15 \%$, but it is systematic, and thus needs to be accounted for. For observation periods of some years to several decades featuring significant changes in glacier volume, the density of volume change often lies in the range of $780-880 \mathrm{~kg} \mathrm{~m}^{-3}$, both for positive and negative mass balances. For the particular case of strong changes in mass balance gradients together with limited mass gain/loss, $f_{\Delta V}$ can however also be systematically higher than the ice density as opposite signs of elevation changes in the accumulation and the ablation area can compensate for each other in terms of volume. If short time intervals $(1-3 \mathrm{yr})$ in a fluctuating mass balance signal are considered, and/or the volume changes over the observation period are small, $f_{\Delta V}$ can show an erratic behavior and may assume values of $0-2000 \mathrm{~kg} \mathrm{~m}^{-3}$ and beyond.

The findings of this study are in line with the simple assessment of $f_{\Delta V}$ by Sapiano et al. (1998) but highlights the strong variability, the underlying processes and the problems inherent to assuming a constant factor to convert geodetic glacier volume change to mass change. $f_{\Delta V}=850 \pm$ $60 \mathrm{~kg} \mathrm{~m}^{-3}$ is recommended in the case of periods longer than $5 \mathrm{yr}$, with stable mass balance gradients, the presence of a firn area, and volume changes significantly different from zero. The conversion factor can however strongly diverge from this mean value for particular conditions, and the density assumption might represent a significant component of uncertainty in geodetically determined mass balances that is larger than previously assumed.

Acknowledgements. This study was triggered by discussions at a WGMS organized workshop on the "measurement and uncertainty assessment of glacier mass balance" held at Tarfala, Sweden, in July 2012. M. Funk and M. Hoelzle provided helpful comments on an earlier version of the manuscript. Reviews by an anonymous reviewer and G. Moholdt contributed to the quality of the paper.

Edited by: M. Van den Broeke

\section{References}

Abdalati, W., Krabill, W., Frederick, E., Manizade, S., Martin, C., Sonntag, J., Swift, R., Thomas, R., Yungel, J., and Koerner, R.: Elevation changes of ice caps in the Canadian Arctic Archipelago, J. Geophys. Res., 109, F04007, doi:10.1029/2003JF000045, 2005.

Abermann, J., Fischer, A., Lambrecht, A., and Geist, T.: On the potential of very high-resolution repeat DEMs in glacial and periglacial environments, The Cryosphere, 4, 53-65, doi:10.5194/tc-4-53-2010, 2010.

Ambach, W. and Eisner, H.: Analysis of a $20 \mathrm{~m}$ firn pit on the Kesselwandferner (Ötztal Alps), J. Glaciol., 6, 223-231, 1966.
Arthern, R. and Wingham, D.: The natural fluctuations of firn densification and their effect on the geodetic determination of ice sheet mass balance, Climatic Change, 40, 605-624, 1998.

Bader, H.: Sorge's law of densification of snow on high polar glaciers, J. Glaciol., 2, 319-323, 1954.

Bamber, J. L. and Rivera, A.: A review of remote sensing methods for glacier mass balance determination, Global Planet. Change, 59, 138-148, 2007.

Bauder, A., Funk, M., and Huss, M.: Ice volume changes of selected glaciers in the Swiss Alps since the end of the 19th century, Ann. Glaciol., 46, 145-149, 2007.

Bolch, T., Sandberg Sørensen, L., Simonsen, S. B., Mölg, N., Machguth, H., Rastner, P., and Paul, F.: Mass loss of Greenland's glaciers and ice caps 2003-2008 revealed from ICESat laser altimetry data, Geophys. Res. Lett., 40, 875-881, doi:10.1002/grl.50270, 2013.

Breili, K. and Rolstad, C.: Ground-based gravimetry for measuring small spatial-scale mass changes on glaciers, Ann. Glaciol., 50, 141-147, 2009.

Cogley, J. G.: Geodetic and direct mass balance measurements: comparison and joint analysis, Ann. Glaciol., 50, 96-100, 2009.

Cox, L. H. and March, L. S.: Comparison of geodetic and glaciological mass-balance techniques, Gulkana Glacier, Alaska, USA J. Glaciol., 50, 63-70, 2004.

Cuffey, K. M. and Paterson, W. S. B.: The Physics of Glaciers, 4. edn., Butterworth-Heinemann, Oxford, 704 pp., 2010.

Fischer, A.: Glaciers and climate change: Interpretation of 50 years of direct mass balance of Hintereisferner, Global Planet. Change, 71, 13-26, 2010.

Fischer, A.: Comparison of direct and geodetic mass balances on a multi-annual time scale, The Cryosphere, 5, 107-124, doi:10.5194/tc-5-107-2011, 2011.

Gardelle, J., Berthier, E., and Arnaud, Y.: Slight mass gain of Karakoram glaciers in the early twenty-first century, Nat. Geosci., 5, 322-325, doi:10.1038/ngeo1450, 2012.

Glaciological Reports: The Swiss Glaciers, 1958/59-2006/07, No. 80-128, Yearbooks of the Cryospheric Commission of the Swiss Academy of Sciences (SCNAT), Laboratory of Hydraulics, Hydrology and Glaciology (VAW) of ETH Zürich, 1960-2011.

Greuell, J. and Oerlemans, J.: The evolution of the englacial temperature distribution in the superimposed ice zone of a polar ice cap during a summer season, in: Proceedings of the Symposium on glacier fluctuations and climatic change, edited by: Oerlemans, J., Kluwer Academic Publishers, Dordrecht, 289-304, 1989.

He, Y., Yao, T., Theakstone, W., Cheng, G., Yang, M., and Chen, T.: Recent climatic significance of chemical signals in a shallow firn core from an alpine glacier in the South-Asia monsoon region, J. Asian Earth Sci., 20, 289-296, 2002.

Helsen, M. M., van den Broeke, M. R., van de Wal, R. S. W., van de Berg, W. J., van Meijgaard, E., Davis, C. H., Li, Y., and Goodwin, I.: Elevation changes in Antarctica mainly determined by accumulation variability, Science, 320, 1626-1629, doi:10.1126/science.1153894, 2008.

Herron, M. M. and Langway, C. C.: Firn densification: an empirical model, J. Glaciol., 25, 373-385, 1980.

Hooke, R., Gould, J., and Brzozowski, J.: Near-surface temperatures near and below the equilibrium line on polar and subpolar glaciers, Zeitschrift für Gletscherkunde und Glazialgeologie, 19 , 
$1-25,1983$.

Huss, M., Bauder, A., and Funk, M.: Homogenization of long-term mass balance time series, Ann. Glaciol., 50, 198-206, 2009.

Jacob, T., Wahr, J., Pfeffer, W. T., and Swenson, S.: Recent contributions of glaciers and ice caps to sea level rise, Nature, 482, 514-518, doi:10.1038/nature10847, 2012.

Kaeaeb, A., Berthier, E., Nuth, C., Gardelle, J., and Arnaud, Y.: Contrasting patterns of early twenty-first-century glacier mass change in the Himalayas, Nature, 488, 495-498, doi:10.1038/nature11324, 2012.

Kaser, G., Fountain, A., and Jansson, P.: A manual for monitoring the mass balance of mountain glaciers, UNESCO, 2003.

Kawashima, K. and Yamada, T.: Experimental studies on the transformation from firn to ice in the wet-snow zone of temperate glaciers, Ann. Glaciol., 24, 181-185, 1996.

Kreutz, K. J., Aizen, V. B., Dewayne Cecil, L., and Wake, C. P.: Oxygen isotopic and soluble ionic composition of a shallow firn core, Inilchek glacier, central Tien Shan, J. Glaciol., 47, 548-554, 2001.

Li, J. and Zwally, H. J.: Modeling the density variation in the shallow firn layer, Ann. Glaciol., 38, 309-313, 2004.

Ligtenberg, S. R. M., Helsen, M. M., and van den Broeke, M. R.: An improved semi-empirical model for the densification of Antarctic firn, The Cryosphere, 5, 809-819, doi:10.5194/tc-5-809-2011, 2011.

Matsuoka, K. and Naruse, R.: Mass balance features derived from a firn core at Hielo Patagónico Norte, South America, Arct., Antarct. Alp. Res., 31, 333-340, 1999.

Moholdt, G., Nuth, C., Hagen, J. O., and Kohler, J.: Recent elevation changes of Svalbard glaciers derived from ICESat laser altimetry, Remote Sens. Environ., 114, 2756-2767, 2010.

Nuth, C., Moholdt, G., Kohler, J., Hagen, J. O., and Kääb, A.: Svalbard glacier elevation changes and contribution to sea level rise, J. Geophys. Res., 115, F01008, doi:10.1029/2008JF001223, 2010.

Oerter, H., Reinwarth, O., and Rufli, H.: Core drilling through a temperate Alpine glacier (Vernagtferner, Oetztal Alps) in 1979, Zeitschrift für Gletscherkunde und Glazialgeologie, 18, 1-11, 1982.

Pälli, A., Kohler, J. C., Isaksson, E., Moore, J. C., Pinglot, J. F., Pohjola, V. A., and Samuelsson, H.: Spatial and temporal variability of snow accumulation using ground-penetrating radar and ice cores on a Svalbard glacier, J. Glaciol., 48, 417-424, 2002.

Paul, F. and Haeberli, W.: Spatial variability of glacier elevation changes in the Swiss Alps obtained from two digital elevation models, Geophys. Res. Lett., 35, L21502, doi:10.1029/2008GL034718, 2008.

Reeh, N.: A nonsteady-state firn-densification model for the percolation zone of a glacier, J. Geophys. Res., 113, F03023, doi:10.1029/2007JF000746, 2008.

Reijmer, C. H. and Hock, R.: Internal accumulation on Storglaciären, Sweden, in a multi-layer snow model coupled to a distributed energy- and mass-balance model, J. Glaciol., 54, 61-72, 2008.
Rignot, E., Rivera, A., and Casassa, G.: Contribution of the Patagonia Icefields of South America to sea level rise, Science, 302, 434-437, doi:10.1126/science.1087393, 2003.

Sapiano, J., Harrison, W. D., and Echelmeyer, K. A.: Elevation, volume and terminus changes of nine glaciers in North America, J. Glaciol., 44, 119-135, 1998.

Schiefer, E., Menounos, B., and Wheate, R.: Recent volume loss of British Columbian glaciers, Canada, Geophys. Res. Lett., 34, L16503, doi:10.1029/2007GL030780, 2007.

Schneider, T. and Jansson, P.: Internal accumulation in firn and its significance for the mass balance of Storglaciären, Sweden, J. Glaciol., 50, 25-34, 2004.

Sharp, R. P.: Features of the firn on Upper Seward Glacier St. Elias Mountains, Canada, J. Geol., 59, 599-621, 1951.

Shiraiwa, T., Kohshima, S., Uemura, R., Yoshida, N., Matoba, S., Uetake, J., and Angelica Godoi, M.: High net accumulation rates at Campo de Hielo Patagónico Sur, South America, revealed by analysis of a $45.97 \mathrm{~m}$ long ice core, Ann. Glaciol., 35, 84-90, 2002.

Sørensen, L. S., Simonsen, S. B., Nielsen, K., Lucas-Picher, P., Spada, G., Adalgeirsdottir, G., Forsberg, R., and Hvidberg, C. S.: Mass balance of the Greenland ice sheet (2003-2008) from ICESat data - the impact of interpolation, sampling and firn density, The Cryosphere, 5, 173-186, doi:10.5194/tc-5-173-2011, 2011.

Suslov, V. and Krenke, A.: Lednik Abramov, Hydromet Publishing, 1980.

Thibert, E., Blanc, R., Vincent, C., and Eckert, N.: Glaciological and volumetric mass balance measurements error analysis over 51 years for the Sarennes glacier, French Alps, J. Glaciol., 54, 522-532, 2008.

Vimeux, F., Ginot, P., Schwikowski, M., Vuille, M., Hoffmann, G., Thompson, L. G., and Schotterer, U.: Climate variability during the last 1000 years inferred from Andean ice cores: a review of methodology and recent results, Palaeogeogr. Palaeocl., 281, 229-241, 2009.

WGMS: Fluctuations of Glaciers, 2000-2005, Vol. IX, ICSU(FAGS)/IUGG(IACS)/UNEP/UNESCO/WMO, World Glacier Monitoring Service, Zurich, Switzerland, 2008.

Zdanowicz, C., Smetny-Sowa, A., Fisher, D., Schaffer, N., Copland, L., Eley, J., and Dupont, F.: Summer melt rates on Penny Ice Cap, Baffin Island: Past and recent trends and implications for regional climate, Journal of Geophysical Research: Earth Surface, 117, F02006, doi:10.1029/2011JF002248, 2012.

Zemp, M., Jansson, P., Holmlund, P., Gärtner-Roer, I., Koblet, T., Thee, P., and Haeberli, W.: Reanalysis of multi-temporal aerial images of Storglaciären, Sweden (1959-99) - Part 2: Comparison of glaciological and volumetric mass balances, The Cryosphere, 4, 345-357, doi:10.5194/tc-4-345-2010, 2010.

Zemp, M., Thibert, E., Huss, M., Stumm, D., Rolstad Denby, C., Nuth, C., Nussbaumer, S. U., Moholdt, G., Mercer, A., Mayer, C., Joerg, P. C., Jansson, P., Hynek, B., Fischer, A., Escher-Vetter, H., Elvehøy, H., and Andreassen, L. M.: Uncertainties and reanalysis of glacier mass balance measurements, The Cryosphere Discussions, 7, 789-839, doi:10.5194/tcd-7-789-2013, 2013. 